\title{
Demystifying Moral Damages in International Investment Arbitration
}

\author{
Simon Weber \\ Ph.D. Researcher, King's College London, London, United Kingdom \\ Simon.Weber@kcl.ac.uk
}

\begin{abstract}
Claims for compensation of material damages in investment arbitration are well known - they are part of every dispute. Tribunals deal extensively with such claims and do not accord much attention to another type of damages: moral damages. Until today, no uniform solution has been found. There seems to be stark disagreement between arbitral tribunals on how to deal with a claim for moral damages. This article sheds light on moral damages and proposes a possible solution under international law. To this end, it introduces the concept of moral damages and its history in international disputes. After having set out such general overview, it then applies the concept to investment arbitration by analysing five issues arbitral tribunals have been faced with when confronted by a claim for moral damages. Finally, it comments on the most prominent awards and provides an outlook for a possible solution.
\end{abstract}

\section{Keywords}

moral damage - immaterial damage - reparation - investment arbitration international dispute resolution - monetary satisfaction - compensation - reputation - psychological harm - Benvenuti \& Bonfant - Desert Line - Lemire - Pezold

\section{Introduction}

\subsection{Background}

On 4 October 2019, an ICSID tribunal rendered an award rejecting a claim for moral damages in a dispute between a group of Turkish businessmen and the 
State of Uzbekistan. ${ }^{1}$ However, the tribunal did not touch on the substance of the discussion surrounding moral damages. It merely denied its own jurisdiction on the moral damages claim, concluding that the bilateral investment treaty (BIT) in question does not protect "investors" but only "investments". ${ }^{2}$ As a result, the harm suffered by the group of businessmen, who were allegedly physically mistreated and tortured by the Uzbek authorities, ${ }^{3}$ was not discussed by the arbitral tribunal. However, in previous disputes claims for moral damages have made it through the jurisdiction phase and were considered by arbitral tribunals in the merits phase. It is not only the acceptance of the existence of moral damages but also the granting of reparation for moral damages to injured parties that is undisputed in public international law. Whereas certain tribunals have rejected claims for moral damages after reviewing the circumstances at stake, ${ }^{4}$ or declared those claims inadmissible due to the time they were invoked, ${ }^{5}$ or due to the lack of a malicious act by the State, ${ }^{6}$ other tribunals have accepted such claims. ${ }^{7}$ Nonetheless, against the backdrop of the proliferation of international investment awards, there seems to be significant disagreement as to how claims for moral damages are to be treated under international investment law if the underlying agreement does not contain any express rules. The aim of this article is to provide an overview of the issues arbitral tribunals have faced when questions relating to moral damages arose and their attempts to resolve these issues.

First, this article briefly touches upon the history of moral damages in international disputes, analysing the decision of the United States-Germany Mixed Claims Commission in the Lusitania case (1923) and the decision of the Permanent Court of International Justice in the Chorzów Factory case (1928), where both agreed that moral damages can be compensated and that the reparation needs to wipe out all consequences of the wrongful act. Whereas these disputes were pure State-to-State disputes, their solutions inspired many later investment tribunals when deciding a dispute.

1 Cosmo Sanderson, "Uzbekistan Liable for Seizure of Shopping Mall" (2019), Global Arbitration Review, reporting on Güneş Tekstil Konfeksiyon Sanayi ve Ticaret Limited Şirketi and Others v. Republic of Uzbekistan (ICSID Case No. ARB/13/19).

2 Ibid.

3 Ibid.

4 Biwater Gauff (Tanzania) Ltd. v. United Republic of Tanzania, ICSID Case No. ARB/05/22.

5 Bernardus Henricus Funnekotter and Others v. Republic of Zimbabwe, ICsID Case No. AR B / o5/6 $5^{2}[140]$.

6 Hesham Talaat M. Al-Warraq v. the Republic of Indonesia, UnCitral, Final Award, 15 December 2014 [654].

7 Desert Line Projects LLC v. The Republic of Yemen, ICSID Case No. ARB/o5/17; SARL Benvenuti \& Bonfant v. People's Republic of the Congo, ICSID Case No. ARB $/ 77 / 2$; Bernhard von Pezold and Others v. Republic of Zimbabwe, ICSID Case No. ARB/10/15, Award, 28 July 2016. 
Second, this article sets out five problems that arbitral tribunals encounter when claimants request reparation for moral damages. The main problem is the following: What is the appropriate reparation for moral damages? As warrants any discussion of the nature of a moral damage, this article dedicates a considerably long section to this first problem. Moreover, it analyses whether a corporation can claim reparation for moral damages suffered by its employees, concluding that a legal entity can only suffer from reputational damage. Additionally, this article addresses the fact that tribunals have had difficulties in establishing a causal link between a State's measure and the moral damage. Fourthly, the present article addresses the punitive character of some decisions on moral damages. This is because according compensation for moral damages to investors suffering at the hands of States that have acted maliciously can have a punitive character, which is prohibited under international economic law. Finally, I evoke the situation in which a State can claim moral damages - which is possible but must be accompanied by the correct remedy.

Third, the article turns to the most important decisions on moral damages. It examines the arbitral award in Benvenuti \& Bonfant S.r.l. v. Congo (1980), which, according to some authors, allegedly constitutes the starting point of moral damages in investment arbitration. It then criticises the award in Desert Line v. Yemen (2008) for its insufficient reasoning, as well as the subsequent decision in Pezold v. Zimbabwe (2016). Those tribunals awarded compensation to the investor for moral damages. Finally, the article concludes that the Lemire test combined with the Victor Pey Casado obiter is plausible and that under current international law there are two available remedies: monetary satisfaction; as well as satisfaction in its purest form. This follows in line with the principles that have been established regarding moral damages in international law.

\subsection{The Concept of Moral Damages}

To understand the issues arising out of these claims, one must first understand what moral damages are. Yet, there is no clear answer to this question. The simplest definition of a moral damage is "a damage that is not material". ${ }^{8}$ A material damage is a financial or economic loss and can therefore be expressed in monetary terms. ${ }^{9}$ On the contrary, a moral damage cannot be expressed in monetary terms and hence cannot be objectively quantified. Two commentaries illustrate examples of moral damages:

8 Ahmadou Sadio Diallo (Republic of Guineav. Democratic Republic of the Congo), Compensation, Judgment, I.C.J. Reports 2012, p. 324, para. 18.

9 S. Wittich, "Non-Material Damage and Monetary Reparation in International Law", 15 Finnish Y.B. Int'l L. (2004), 329. (He uses the term "non-material" instead of "moral" or "immaterial" damage); P. Dumberry, "Compensation for Moral Damages in Investor-State Arbitration Disputes”, 27(3) Journal of International Arbitration (2010), 247-276, at 258. 
Damages for bodily or mental harm, for mistreatment during detention, or for deprivation of liberty shall include compensation for past and prospective: (a) harm to the body or mind; (b) pain, suffering and emotional distress. ${ }^{10}$

and

Non-material damage is generally understood to encompass loss of loved ones, pain and suffering as well as the affront to sensibilities associated with an intrusion on the person, home or private life. ${ }^{11}$

In brief, a moral damage includes all forms of physical and psychological violence as well as harm to one's reputation. ${ }^{12}$ It is immaterial and does not affect the victim's assets. ${ }^{13}$ This conceptual specificity, which clearly draws a line between damages that are financially assessable or not, is also included in the International Law Commission (ILC) Commentary on Article 36 of the Draft Articles on Responsibility of States for Internationally Wrongful Acts. Said commentary explains that compensation must correspond to financially assessable damages, a condition which will become relevant later in this article. ${ }^{14}$

Some authors attempt to build a bridge between moral damages in investment arbitration and in international human rights law - yet, the comparison is inadequate. ${ }^{15}$ This is for one simple reason. Investment law protects the economic interests of foreign investors, whereas human rights law protects the fundamental freedoms of individuals residing in the territory of a State. ${ }^{16}$

10 Article 28 of the 1961 Harvard Draft Convention on the International Responsibility of States for Injuries to Aliens, 15 April 1961, by reporters L.B. Sohn and R. Baxter, 55 A.J.I.L. (1961), 548 .

11 Draft Articles on Responsibility of States for Internationally Wrongful Acts, with commentaries 2001, Report of the ILC on the work of its Fifty-third Session, Official Records of the General Assembly, Fifty-sixth Session, Supplement No. 10 ((A/56/10), Ch. IV.E.2) ('ILC Commentaries'), Article 36, para. 16.

12 S. Wittich, supra note 9, 329.

13 Caroline Breton, "Le Dommage dans l'arbitrage d'investissement", para. 315.

14 Article 36 of the Draft Articles on Responsibility of States for Internationally Wrongful Acts, with commentaries 2001, Report of the ILC on the work of its Fifty-third Session, Official Records of the General Assembly, Fifty-sixth Session, Supplement No. 10 ((A/56/10), Ch. IV.E.2), para. 4.

15 For further discussion, see Julien Cazala, La réparation du préjudice moral dans le contentieux international de l'investissement (Pedone, 2015), 282.

16 European Convention on Human Rights, Rome 1950, Preamble. 


\subsection{Lusitania - The Early Days}

One of the early cases in which an international dispute resolution body had to deal with a claim for moral damages was the Lusitania case decided by the United States-Germany Mixed Claims Commission in 1923. In this case a German submarine was responsible for the sinking of the British cruise liner 'Lusitania' during WWII, which caused the death of 1,198 people, including 128 American citizens. ${ }^{17}$ As to the moral damages claimed, the Commission stated:

(t)hat one injured is, under the rules of international law, entitled to be compensated for an injury inflicted resulting in mental suffering, injury to his feelings, humiliation, shame, degradation, loss of social position or injury to his credit or to his reputation, there can be no doubt, and such compensation should be commensurate to the injury. Such damages are very real, and the mere fact that they are difficult to measure or estimate by money standards makes them nonetheless real and affords no reason why the injured person should not be compensated therefor as compensatory damages, but not as a penalty. $(. . .)^{18}$

This decision constitutes one of the first occasions where an international dispute resolution body recognised in an opinion that a moral damage needs to be repaired and that this reparation needs to be proportional to the inflicted damage. By using the term "one injured", the commission also includes both natural and juridical persons to be entitled to claim reparation for moral damages. Furthermore, the Mixed Claims Commission stated that the mere fact that pecuniary quantification of the damage may be difficult does not take away the legitimacy of the remedy. In the opinion, the Mixed Claims Commission addressed "mental suffering" at length and argued that there is no "reason why the wrongdoer should escape repairing his wrong or why he who has suffered should not receive reparation therefor measured by rules as nearly approximating accuracy as human ingenuity can devise". ${ }^{19}$ However, the Commission omitted to address two points. First, it did not explain how the damage can be quantified or "measured", which constitutes a major problem. Second, it did not address the available remedies under international law.

\footnotetext{
17 Opinion in the Lusitania Cases, United States-Germany Mixed Claims Commission, 1923, VII U.N.R.I.A.A. 32, para. 32 .

18 Ibid., para. 40.

19 Ibid., p. 36.
} 
Of course, in 1923, international law was not as developed as it is today. Yet, the Commission left out a discussion, which could have led to a different conclusion. This is a conclusion that the present article develops below.

\subsection{Chorzów - No Distinction between Material and Moral Damages}

Five years later, in 1928, the Permanent Court of International Justice (PCIJ) rendered a decision on the customary international law standard of compensation for damages caused by internationally wrongful acts in the Chorzów case. ${ }^{20}$ It decided not to make a distinction between material and moral damages, but rather confirmed that the reparation needs to be awarded. To this end, the PCIJ stated that said reparation must be based on objective criteria and it needs to wipe out all the consequences of the wrongful act. This was explained in the following paragraph of the decision, which is often cited by international arbitral tribunals that award compensation: ${ }^{21}$

(t)he essential principle contained in the actual notion of an illegal act - a principle which seems to be established by international practice and in particular by the decisions of arbitral tribunals - is that reparation must, as far as possible, wipe-out all the consequences of the illegal act and re-establish the situation which would, in all probability, have existed if that act had not been committed. Restitution in kind, or, if this is not possible, payment of a sum corresponding to the value which a restitution in kind would bear; the award, if need be, of damages for loss sustained which would not be covered by restitution in kind or payment in place of it - such are the principles which should serve to determine the amount of compensation due for an act contrary to international law. ${ }^{22}$

20 Case concerning the factory at Chorzów (Claim for indemnity) (Germany v. Poland), ${ }_{13}$ September 1928, Merits, P.C.I.J., Series A, No. 17, at Legal Authorities No. 83.

21 The tribunal in Siag referred to the judgment as the "oft-cited Chorzów Factory case". Waguih Elie George Siag and Clorinda Vecchi v. the Arab Republic of Egypt, ICSID Case No. ARB/05/15, Award, 1 June 2009, para. 545. The tribunal in ADC v. Hungary decided that a distinction needs to be made between the standard for compensation in the case of a lawful expropriation and an unlawful expropriation: the first refers to the standard stemming from the BIT, the second refers to the standard of customary international law as stated in the Chorzów case (ADC Affiliate Ltd. and ADC and ADMC Management Ltd. v. Hungary, ICSID Case No. ARB/o3/16, Final Award on Jurisdiction, Merits and Damages, IIC 1 (2006), paras. 480-499).

22 Case concerning the factory at Chorzów (Claim for indemnity) (Germany v. Poland), 13 September 1928, Merits, P.C.I.J., Series A, No. 17, at Legal Authorities No. 83, para. 125. 
The core message of this paragraph is clear: the reparation needs to wipe out all the consequences of the wrongful act and re-establish - as far as possible the original situation. In this decision, the $\mathrm{PCIJ}$ established a principle of customary international law, which has been applied many times over the years. ${ }^{23}$

\subsection{Current Developments - the ARsIWA and the Diallo Case}

The International Law Commission codified these principles in 2001 in the Articles on the Responsibility of States for Internationally Wrongful Acts (ARSIWA) by introducing Article $31,{ }^{24}$ which sets out that a State needs to repair any damage it has caused when committing an internationally wrongful act. ${ }^{25}$ The very same provision goes even further by clarifying that the term "damage" includes "any damage, whether material or moral, caused by the internationally wrongful act". ${ }^{26}$ Hence, the ILC undoubtedly recognises the existence of the concept of moral damages; ${ }^{27}$ moreover, reparation is required. However, the form of the reparation is not defined any further, which thus poses an issue, as we shall see later. ${ }^{28}$

In 2012, the International Court of Justice (ICJ) confirmed this principle in the famous Diallo case. Mr. Diallo, a Guinean citizen, saw his rights stemming from the International Covenant on Civil and Political Rights and from the African Charter on Human and Peoples' Rights violated by the Democratic

23 The tribunal in Siag referred to the judgment as the "oft-cited Chorzów Factory case". Waguih Elie George Siag and Clorinda Vecchiv the Arab Republic of Egypt, ICsid Case No. ARB/05/15, Award, 1 June 2009, para. 545. The tribunal in ADC v. Hungary decided that a distinction needs to be made between the standard for compensation in the case of a lawful expropriation and an unlawful expropriation: the first refers to the standard stemming from the вгт, the second refers to the standard of customary international law as stated in the Chorzów case (ADC Affiliate Ltd. and ADC and ADMC Management Ltd. v. Hungary, ICSID Case No. ARB/o3/16, Final Award on Jurisdiction, Merits and Damages, IIC 1 (2006), paras. 480-499).

24 James Crawford, International Law Commission, Draft articles on Responsibility of States for Internationally Wrongful Acts 2001 (Cambridge: Cambridge University Press, 2002).

25 Article 31(2) of the Draft Articles on Responsibility of States for Internationally Wrongful Acts 2001, Report of the ILC on the work of its Fifty-third Session, Official Records of the General Assembly, Fifty-sixth Session, Supplement No. 10 ((A/56/10), Ch. IV.E.2).

26 Ibid.

27 For further information, see Draft Articles on Responsibility of States for Internationally Wrongful Acts, with commentaries 2001, Report of the ILC on the work of its Fifty-third Session, Official Records of the General Assembly, Fifty-sixth Session, Supplement No. 10 ((A/56/10), Ch. IV.E.2), Article 31.

28 See the discussion of the ILC commentary at pp. 428-429. 
Republic of the Congo. ${ }^{29}$ By deciding in Mr. Diallo's favour, the ICJ confirmed the Chorzow principle. It defined the term "moral damage" as follows: moral damage "covers harm other than material injury which is suffered by an injured entity or individual". ${ }^{30}$ It further confirmed that a "[n]on-material injury to a person which is cognizable under international law may take various forms", by referring not only to the Lusitania case, but also to the definition applied by the Inter-American Court of Human Rights. ${ }^{31}$

Even though the ARsiWA themselves are not legally binding, they are seen as a codification of customary international law. ${ }^{32}$ Together with the jurisprudence constante of the ICJ, the principle enshrined in Article 31 ARSIWA is therefore clearly part of customary international law. However, in the sphere of international investment arbitration, the application and implementation of this principle have already caused trouble for different arbitral tribunals that have had to deal with a claim for moral damages.

\section{Issues Arbitral Tribunals Have Been Faced with over Time}

To be able to discuss the issues surrounding moral damages, it is necessary to briefly remind the reader that not all international agreements protect "investors", but "investments" only. As it is difficult to argue that an investment can suffer from a moral damage, the following discussion must be read in the light of the assumption that the arbitral tribunal has confirmed its jurisdiction and has declared the claim for moral damages admissible. Having analysed the arbitral decisions rendered by arbitral tribunals that have been faced with claims for moral damages, five issues can be observed. These are:

- What is the adequate form of reparation given that moral damages cannot be quantified?

- Can corporations claim moral damages suffered by their employees?

- How does one prove a moral damage?

- Can punitive damages be awarded?

- Can States use counterclaims alleging moral damages?

29 Ahmadou Sadio Diallo (Republic of Guinea v. Democratic Republic of the Congo), Compensation, Judgment, I. C.J. Reports 2012, p. 324.

$30 \quad$ Ibid., p. 324, para. 18.

$31 \quad$ Ibid.

32 On 12 December 2001, the General Assembly of the United Nations adopted Resolution $56 / 83$, which "commends them to the attention of Governments without prejudice to the question of their future adoption or other appropriate action". UN General Assembly Resolution 56/83, "Responsibility of States for Internationally Wrongful Acts", UN Doc. A/Res/56/83, 12 December 2001, para. 3 . 
The following section addresses the five questions, focusing particularly on the first - how do you repair a moral damage? To this, the present article now turns.

\subsection{How to Repair a Moral Damage}

When an arbitral tribunal confirms a claim for moral damages, it has to decide on the appropriate remedy for the breach of an obligation. Under international law the principle is clear: a breach of an engagement involves an obligation to make reparation in an adequate form. ${ }^{33}$ In this case, reparation means recompense given to one who has suffered legal injury at the hands of another. ${ }^{34}$ As a consequence, a new obligation, distinct from the primary obligation that was breached, is being created. ${ }^{35}$ Whereas awarding compensation is rather straightforward when it comes to material damages, which have a "price tag", the situation changes with regard to immaterial damages: How can they be correctly repaired? In order to discuss this question, the following section first introduces the remedies that are available under international law, and thereafter it moves on to a discussion of the adequate reparation for moral damages.

\subsubsection{Restitution and Compensation in Context}

Under international law, there are three established forms of reparation. Article 34 ARSIWA establishes that reparation shall take the form of restitution, compensation and satisfaction. Whereas restitution means re-establishment of the situation which existed before the breach, compensation consists of an award of money to the victim. Finally, satisfaction can consist of an acknowledgement of the breach or a formal apology.

In order to clarify how to find an adequate form of reparation, the ILC referred in its comments to ARSIWA to the Factory at Chorzów case, in which the injury was of a material nature. The PCIJ dealt only with two forms of reparation: restitution and compensation. ${ }^{36}$ As to satisfaction, the ILC further stated that

In certain cases, satisfaction may be called for as an additional form of reparation. Thus, full reparation may take the form of restitution,

33 Case concerning the factory at Chorzów (Claim for indemnity) (Germany v. Poland), 13 September 1928, Jurisdiction, P.C.I.J., Series A, No. 9, p. 21; According to Vattel, every State has the right to obtain complete reparation if it has suffered a prejudice. E. De Vattel, The Law of Nations or Principles of the Law of Nature (4th edition, London: Clark and Sons, 1811), 155, para. 51 .

34 D. Shelton, "Reparations", Max Planck Encyclopaedia of Public International Law (2015), para. 1.

35 Ibid., para. 7 .

$36 \quad$ Factoryat Chorzów, Merits, p. 47. 
compensation and satisfaction, as required by the circumstances. Article 34 also makes it clear that full reparation may only be achieved in particular cases by the combination of different forms of reparation. For example, re-establishment of the situation which existed before the breach may not be sufficient for full reparation because the wrongful act has caused additional material damage (e.g. injury flowing from the loss of the use of property wrongfully seized). Wiping out all the consequences of the wrongful act may thus require some or all forms of reparation to be provided, depending on the type and extent of the injury that has been caused. ${ }^{37}$

This accords with the ICJ's decision in the Avena case. In Avena, the Court held that what constitutes "reparation in an adequate form" clearly varies depending upon the concrete circumstances surrounding each case and the precise nature and scope of the injury. ${ }^{38}$

Let us rethink what is the objective of each of the three types of reparation. The idea of restitution is to re-establish the statu quo ante - the situation that existed before the breach. ${ }^{39}$ In some situations however restitution is impossible. In Aminoil, a decree issued by the Government of Kuwait annulled a concession held by the investor. The parties agreed that the re-establishment of the initial situation was impossible because the intangible nature of a moral (immaterial) damage excludes restitution as a form of reparation. ${ }^{40}$ Therefore, restitution is not an available remedy for the reparation of moral damages.

The second form of reparation is compensation. ${ }^{41}$ Its objective is to compensate the quantifiable damages the victim has suffered. ${ }^{42}$ In the

37 Article 34, commentary, para. 2, p. 95 of the Draft Articles on Responsibility of States for Internationally Wrongful Acts, with commentaries 2001, Report of the ILC on the work of its Fifty-third Session, Official Records of the General Assembly, Fifty-sixth Session, Supplement No. 10 ((A/56/10), Ch. IV.E.2).

38 Avena and other Mexican Nationals (Mexico v. United States of America), Judgment, I.C.J. Reports 2004, p. 12, para. 119 .

39 Article 35 of the Draft Articles on Responsibility of States for Internationally Wrongful Acts 2001, Report of the ILC on the work of its Fifty-third Session, Official Records of the General Assembly, Fifty-sixth Session, Supplement No. 10 ((A/56/10), Ch. IV.E.2).

40 Government of Kuwait v. American Independent Oil Company (1982), I.L.R., Vol. 66, p. 533.

41 Article 36 of the Draft Articles on Responsibility of States for Internationally Wrongful Acts 2001, Report of the ILC on the work of its Fifty-third Session, Official Records of the General Assembly, Fifty-sixth Session, Supplement No. 10 ((A/56/10), Ch. IV.E.2).

42 D. Shelton, "Reparations", Max Planck Encyclopaedia of Public International Law (2015), para. 25; Article 36 of the Draft Articles on Responsibility of States for Internationally 
Gabcikovo-Nagymaros case, the ICJ declared that this principle constitutes "a well-established rule of international law that an injured State is entitled to obtain compensation from the State which has committed an internationally wrongful act for the damage caused by it". 43 This also applies to injured investors. ${ }^{44}$ The ICJ's ruling in Gabčikovo-Nagymaros follows in line with the opinion in the Lusitania case, which states that the State, which has committed an internationally wrongful act, has the obligation to compensate any financially evaluable damage incurred by its victim. ${ }^{45}$ This entails an objective element - i.e. the quantification method that is used must clearly lay out how a certain amount of money is justified.

And this is precisely what the arbitral tribunals in Benvenuti, Desert Line and Pezold attempted to do. ${ }^{46}$ All tribunals awarded compensation to the investors. Yet, how can a moral damage be objectively quantified? As already set out earlier, compensation "corresponds to the financially assessable damage suffered by the injured State or its nationals." 47 When the Desert Line tribunal had to decide on the amount of money it would award to the investor it stated that it would estimate the damage on the basis of "objective criteria". Unfortunately, the tribunal was unsuccessful in explaining satisfactorily how it determined the amount awarded to the investor. The arbitrators analysed in depth the different types of damage the investor's employees had suffered and connected them with the damage to its credit and reputation, which had both been caused by the wrongful acts of Yemen. ${ }^{48}$ On this basis, they qualified the damage as

Wrongful Acts, with commentaries 20o1, Report of the ILC on the work of its Fifty-third Session, Official Records of the General Assembly, Fifty-sixth Session, Supplement No. 10 ((A/56/10), Ch. IV.E.2), para. 4.

43 Gabčikovo-Nagymaros Project (Hungary/Slovakia), Judgment, I.C.J. Reports 1997, para. 152.

44 See discussion below in Section 3.2 Moral Damages Suffered by Corporations' Agents.

45 Opinion in the Lusitania Cases, United States-Germany Mixed Claims Commission, 1923, VII U.N.R.I.A.A. 32, 39.

46 Desert Line Projects LLC v. Yemen, ICSID Case No. ARB/05/17, Award, 6 February 2008; SARL Benvenuti \& Bonfant v. People's Republic of the Congo, ICSID Case No. ARB/77/2, Award, 8 August 1980, English translations of French original in 21 I.L.M. (1982), 740 (with correction: 21 I.L.M. (1982)), 1478; 8 Y.B. Comm. Arb. (1983), 144; 1 ICSID Reports (1993), 330; Bernhard von Pezold and Others v. Republic of Zimbabwe, ICSID Case No. ARB/10/15, Award, 28 July 2016, supra note 7 .

47 Article 36 of the Draft Articles on Responsibility of States for Internationally Wrongful Acts, with commentaries 2001, Report of the ILC on the work of its Fifty-third Session, Official Records of the General Assembly, Fifty-sixth Session, Supplement No. 10 ((A/56/10), Ch. IV.E.2), para. 4.

48 Desert Line Projects LLC v. Yemen, ICSID Case No. ARB/05/17, Award, 6 February 2008, para. 290 . 
"substantial". ${ }^{49}$ Yet, the arbitrators pointed out that the amount of money the investor initially claimed was totally "exaggerated" given the relation between the value of the project as a whole and the damages claimed. ${ }^{50}$ As a result, they decided to award USD 1 million to the investor, stating that this amount was merely "symbolic" and "modest" compared to the project as a whole. ${ }^{51}$

However, the tribunal was not able to provide an explanation regarding on which objective basis it had calculated the compensation. This constitutes a major defect in the award. Is there even a way to calculate such compensation?

In this regard, it is interesting to have a look at the ILC's approach and the lacunas in its analysis. In the context of diplomatic protection, the ILC has argued that "[c]ompensable personal injury encompasses not only associated material losses, such as loss of earnings and earning capacity, medical expenses and the like, but also non-material damage suffered by the individual (sometimes, though not universally, referred to as 'moral damage' in national legal systems)."52 Moreover, the ILC is of the opinion that "[m]aterial and moral damage resulting from an internationally wrongful act will normally be financially assessable and hence covered by the remedy of compensation".53 Unfortunately, the ILC failed to explain how compensation for such moral damages can be quantified. ${ }^{54}$ The ILC went on to state that some arbitral tribunals awarded "set amount[s]" of money. 55

Furthermore, the ILC commented that

[i]n accordance with paragraph 2 of article 31, the injury for which a responsible State is obliged to make full reparation embraces 'any damage, whether material or moral, caused by the internationally wrongful act of a State'. Material and moral damage resulting from an internationally wrongful act will normally be financially assessable and hence covered by the remedy of compensation. ${ }^{56}$

\section{Ibid.}

$50 \quad$ Ibid.

$51 \quad$ Ibid.

$5^{2}$ Article 36 of the Draft Articles on Responsibility of States for Internationally Wrongful Acts, with commentaries 2001, Report of the ILC on the work of its Fifty-third Session, Official Records of the General Assembly, Fifty-sixth Session, Supplement No. 10 ((A/56/10), Ch. IV.E.2), para. 16.

53 Ibid., Article 37, 3.

54 See the discussion of quantification methods in ibid., Article $36,21 \mathrm{ff}$.

55 Ibid., Article 36, 18.

56 Article 37(3) of the Draft Articles on Responsibility of States for Internationally Wrongful Acts, with commentaries 2001, Report of the ILC on the work of its Fifty-third Session, 
Whereas the statement as it stands might seem helpful in an attempt to claim compensation, it is not. This is because it does not constitute an objective quantification method. Moral damages, like emotional distress or psychological violence, are simply not objectively quantifiable and no common understanding or calculation mechanism exists in international law that would justify a particular amount of money. Any amount would be completely subjective and hence uncertain. In Rompetrol v. Romania, the arbitral tribunal expressly refused to award damages under the "moral damages" head as Rompetrol failed "to produce any reliably concrete evidence of actual losses". 57 Therefore, the arbitral tribunal had expected to see financially assessable damages or losses on which it could have based an objective quantification.

This follows in line with the Iran-United States Claims Tribunal's decision in Amoco v. Iran, in which the Tribunal clarified that "one of the best settled rules of the law of international responsibility of States" is the following: "no reparation for speculative or uncertain damages can be awarded".58 This principle shows that any arbitral tribunal confronted with a claim for moral damages that awards compensation drifts into speculation. ${ }^{59}$ Any sum of money awarded as compensation is arbitrary as there is no certain means of objectively quantifying a moral damage. If, eventually, States agree on a "table" of noncompensatory damages, as are available under some domestic laws, ${ }^{60}$ or the ICJ introduces a new approach, the situation would look different. Therefore, awarding compensation is administratively unworkable, and no certainty can be established. Any award of compensation would be individual justice and go against the legitimacy and harmony of the system, which should seek systematic justice based on the applicable treaty and international law.

The above paragraphs show us the dilemma. Whereas the ILC points out that moral damages are financially assessable and can be compensated, it

Official Records of the General Assembly, Fifty-sixth Session, Supplement No. 10 ((A/56/10), Ch. IV.E.2).

57 The Rompetrol Group NVv. Romania, ICSID Case No. ARB/o6/3, [293].

58 Amoco International Finance Corp. v. Islamic Republic of Iran, Iran-United States Claims Tribunal, Case No. 56, Partial Award, 14 July 1987, para. 238.

59 In Di Caro (Italyv. Venezuela) (1903), x R.I.A.A., 597, 598 the umpire decided that the loss of a husband "may not be translated into any certain or ascertainable number of bolivars or pounds sterling".

6o See the discussion in Reza Mohtashami QC, Romilly Holland and Farouk El-Hosseny, "GAR Chapter: Non-Compensatory Damages in Civil- and Common-Law Jurisdictions Requirements and Underlying Principles", in John A. Trenor (ed.), The guide to damages in international arbitration (2nd edition, Global Arbitration Review, 2018). 
fails to explain how this can be done objectively and without awarding speculative damages.

\subsubsection{Satisfaction - the Way Out?}

Taking into account the above considerations of the dilemma, two potential options can be discussed, which, however, do not solve the problem in its entirety. First, the present article suggests that monetary satisfaction is a form of reparation that can be awarded by the arbitral tribunal. Second, if the arbitral tribunal considers monetary satisfaction to be overly subjective, it can award satisfaction in its most basic form: declaratory relief. ${ }^{61}$

As a reminder, a moral damage includes all forms of physical and psychological violence as well as harm to one's reputation. ${ }^{62}$ As a result, objective quantification of a moral damage is impossible. This means that compensation "is not a remedy for 'moral' damages." ${ }^{63}$ The question that must be asked here is "what is the monetary value of pain and suffering?" Of course, material damage such as medical bills and lost business opportunities can be objectively quantified. However, pain and suffering must be quantified differently.

If a tribunal decides that monetary reparation is appropriate, any decision as to a specific sum of money would be subjective. Ultimately, given that there is no objective quantification method that can be used to put a number on an investor's suffering, the crucial point is the subjective perception of the damage.

Combining the above with the Chorzow principle (that the reparation must wipe out as far as possible the consequences of the wrongful act), the quantification of the appropriate remedy is debatable. Must it, from an objective perspective and for everyone to understand, repair the investor? Or must the sum of money be subjectively appropriate from the perception of the arbitrators or from that of the investor?

\subsubsection{Monetary Satisfaction}

The ILC suggests that one form of satisfaction may be the payment of money. ${ }^{64}$ In particular, the Commission states that

$61 \quad$ Article 37 of the Draft Articles on Responsibility of States for Internationally Wrongful Acts 2001, Report of the ILC on the work of its Fifty-third Session, Official Records of the General Assembly, Fifty-sixth Session, Supplement No. 10 ((A/56/10), Ch. IV.E.2).

62 S. Wittich, supra note 9, 329.

63 A.C. Smutny, "Some Observations on the Principles Relating to Compensation in the Investment Treaty Context", 22 ICSID Review (2007), 1, 6, fn. 16.

64 Article 37 of the Draft Articles on Responsibility of States for Internationally Wrongful Acts, with commentaries 2001, Report of the ILC on the work of its Fifty-third Session, 
It is true that monetary payments may be called for by way of satisfaction under article 37, but they perform a function distinct from that of compensation. Monetary compensation is intended to offset, as far as may be, the damage suffered by the injured State as a result of the breach. Satisfaction is concerned with non-material injury, specifically non-material injury to the State, on which a monetary value can be put only in a highly approximate and notional way. ${ }^{65}$

Some authors have tried to analyse this statement and stated that the "difference between payments of money by way of compensation and as satisfaction is apparently that in the former case, the level of damages is to be determined mechanically (and hence objectively), in the latter, a global figure is to be taken as representative of injuries that are difficult to quantify". ${ }^{66}$ Generally, taking a global figure is not a surprising approach. Most domestic laws contain a means by which a number can be put on a moral damage. In international law, there is no harmonised solution. However, several authors have expressed sympathy for an appreciation of a monetary reparation of moral damages, ${ }^{67}$ especially in cases where "claimants have suffered grave indignities" ${ }^{68}$ Born suggests in a dissenting opinion in the Biwater Gauff v. Tanzania case that even if the claimant has not suffered from any material loss it has still suffered from a moral damage, the latter constituting an "unacceptable breach of fundamental international rights and protections", 69 which "demands a remedy beyond merely declaring it a violation of the relevant BIт". ${ }^{70} \mathrm{He}$ is also of the opinion that "it is ancient law that there is no right without a remedy (ubi jus ibi remedium) and that adage applies here no less than elsewhere". ${ }^{71}$

This is a fair solution, which can be chosen by the arbitral tribunal. Yet, when doing so, the arbitrators must be aware of three potential weaknesses

Official Records of the General Assembly, Fifty-sixth Session, Supplement No. 10 ((A/56/10), Ch. IV.E.2), 5 .

65 Ibid., Article $36,4$.

66 Matthew T. Parish, Annalise K. Nelson and B. Rosenberg, "Awarding Moral Damages to Respondent States in Investment Arbitration", 23o, http://scholarship.law.berkeley.edu/ bjil/vol29/issi/7, accessed 14 July 2018.

67 Jarrod Wong, "Making a Muddle of Moral Damages", http://arbitrationblog.kluwerarbitration.com/2014/10/13/making-a-muddle-of-moral-damages/.

68 Luke Eric Peterson, "Moral Damages in Investment Arbitration" (2011), Kluwer Arbitration Blog.

69 Biwater Gauffv. Tanzania, ICSID Case No. ARB/05/22, Concurring and Dissenting Opinion of Gary Born, 18 July 2008, para. 33 .

$70 \quad$ Ibid.

$71 \quad$ Ibid., para. 32. 
with regard to this solution. The above paragraphs have already addressed the first weakness: there is no objective quantification method to quantify moral damages. The second weakness concerns the query: whose subjective perspective is determinant for the "full" reparation standard? Finally, the third weakness is that sums of money that are overly high can have a punitive character.

The present article has already laid out that a moral damage cannot be objectively quantified, which excludes an award of compensation. As a consequence, one might point out that a subjective monetary satisfaction cannot be awarded either, as its amount would be speculative. On the other hand, there is a way to argue that monetary satisfaction is the appropriate remedy for moral damages. In Certain Activities Carried out by Nicaragua, the ICJ addressed a situation in which the valuation of material damages and their compensation was difficult. ${ }^{72}$ Of course, the situation is different to the one discussed in this article, as the ICJ addressed a situation whereby there was an absence of adequate evidence of the material damage in question. Nonetheless, the references relied on by the ICJ are helpful and the underlying rationale can be transposed to awarding a monetary remedy in reparation of a moral damage. The ICJ referred to the Diallo and the Trail Smelter cases. In both of those cases the valuation of the material damages had been difficult, in addition to there being a lack of sufficient evidence of such damages. In both cases, the judges and arbitrators held that in such situations it is "appropriate to award compensation based on equitable considerations". ${ }^{73}$ This is because if the amount of the damages cannot be ascertained with certainty,

it would be a perversion of fundamental principles of justice to deny all relief to the injured person, and thereby relieve the wrongdoer from making any amend for his acts. In such case, while the damages may not be determined by mere speculation or guess, it will be enough if the evidence shows the extent of the damages as a matter of just and reasonable inference, although the result be only approximate. ${ }^{74}$

To clarify, the damages discussed in terms of a lack of evidence were of a material nature - and hence compensation was the appropriate remedy. Of course,

72 Certain Activities Carried out by Nicaragua in the Border Area (Costa Rica v. Nicaragua), Judgment, I.C.J. Reports 2018, p. 15 [35].

73 Ahmadou Sadio Diallo (Republic of Guinea v. Democratic Republic of the Congo), Compensation, Judgment, I.C.J. Reports 2012 [33].

Trail Smelter Case (United States, Canada) (1938), III R.I.A.A., pp. 1905-1982, 1920. 
the tangible nature of material damages makes it easier to assess the extent of such damage, albeit in the presence of a paucity of evidence. This cannot, however, be applied to a theoretical award of compensation for moral damages. This is because the solution would go too far - in other words, the award of compensation should be ascertained objectively as much as possible.

Yet, the underlying ratio stemming from the Nicaragua decision, can be applied to monetary satisfaction. The "unacceptable breach of fundamental international rights and protections", ${ }^{75}$ must result in the wrongdoer making amends that have an effect of reparation. As a result, it would be possible, according to the Nicaragua ratio, to award monetary satisfaction based on equitable considerations in order to repair a moral damage.

Second, imagine the situation in which an arbitral tribunal were to award monetary satisfaction for a moral damage. The goal of the reparation must still be to wipe out all the consequences of the unlawful act and make the investor whole again. Yet, it is unclear from whose subjective point of view the reparation must be "full". Is it the perception of the arbitral tribunal or the perception of the investor that is determinant? As the subjective perception of the investor is hard to objectively prove and potentially difficult to comprehend for the arbitral tribunal, the most practical solution is the subjective perception of the arbitral tribunal. Consequently, it can be expected that a decision on a sum of money to be awarded is always rooted in a set of societal values with which the decision makers are the most acquainted. Moreover, as already noted above, that monetary satisfaction will be based on equitable considerations by the arbitral tribunal. As a result, the arbitrators' subjective perception of the monetary value of the investor's pain and suffering is determinant for the amount to be awarded as satisfaction.

Third, there is the danger of awarding overly high sums of money, which can give the award a punitive character. As will be addressed below, in public international law neither punitive damages nor a justification for punitive damages exists. ${ }^{76}$ These criminal law concepts have no place in international law: States are sovereign and they cannot be punished. ${ }^{77}$

75 Biwater Gauffv. Tanzania, ICsid Case No. ARB/05/22, Concurring and Dissenting Opinion of Gary Born, 18 July 2008, para. 33 .

$7^{6}$ Stephen Jagusch and Thomas Sebastian, "Moral Damages in Investment Arbitration: Punitive Damages in Compensatory Clothing?", 29 Arbitration International (2013), 58, https://academic.oup.com/arbitration/article-abstract/29/1/45/213073. 


\subsubsection{Satisfaction through Declaratory Relief}

Another conceptually satisfactory, yet practically unsatisfactory, solution can be an award of declaratory relief. This solution was applied by the arbitral tribunal in Victor Pey Casado \& President Allende Foundation v. Chile. Whereas the arbitral tribunal refused to award moral damages, the arbitrators added in obiter that the acknowledgment of the investor's moral damages in connection with the compensation that was being awarded for other breaches would already constitute a substantial and sufficient satisfaction to repair the moral damage. ${ }^{78}$ This concept of "declaratory relief" as a form of reparation has already been accepted by the ILC in the case of non-material damages. ${ }^{79}$

According to Hoss, satisfaction is supposed to repair the immaterial damages that have been caused by a wrongful act. ${ }^{80}$ In accordance with Article 37(2) ARSIWA, it would therefore suffice, in order to acknowledge the breach, to order the State to express its regrets or to issue a formal apology. This is common practice in international law, ${ }^{81}$ which recognises that satisfaction is a "possible sanction in appropriate circumstances". ${ }^{82}$

In this regard, the arbitral tribunal in the Rainbow Warrior case stated that

There is a long-established practice of States and international Courts and Tribunals of using satisfaction as a remedy or form of reparation (in the wide sense) for the breach of an international obligation. This practice relates particularly to the case of moral or legal damage done directly to the State, especially as opposed to the case of damage to persons involving international responsibilities. The whole matter is valuably

78 Victor Pey Casado \& President Allende Foundation v. Chile, ICSID Case No. ARB/98/2, Award, 8 May 2008, paras. 689 and 704.

79 Article 37 of the Draft Articles on Responsibility of States for Internationally Wrongful Acts, with commentaries 2001, Report of the ILC on the work of its Fifty-third Session, Official Records of the General Assembly, Fifty-sixth Session, Supplement No. 10 ((A/56/10), Ch. IV.E.2), para. 6.

80 C. Hoss, "Satisfaction", Max Planck Encyclopaedia of Public International Law (2011), paras. 1,2 .

81 See Rainbow Warrior (New Zealand/France), XX U.N.R.I.A.A., pp. 272 and 273, para. 122; LaGrand (Germany v. United States of America), Judgment, I.C.J. Reports 2001, p. 466, para. 125 and Operative Clause 7; Article 37, para. 4 of the Draft Articles on Responsibility of States for Internationally Wrongful Acts, with commentaries 2001, Report of the ILC on the work of its Fifty-third Session, Official Records of the General Assembly, Fifty-sixth Session, Supplement No. 10 ((A/56/10), Ch. IV.E.2).

82 Bernd Ehle and Martin Dawidowicz, "Chapter 10: Moral Damages in Investment Arbitration, Commercial Arbitration and WTO Litigation", in J.A. Huerta-Goldman, A. Romanetti and F.X. Stirnimann (eds.), WTO Litigation, Investment Arbitration and Commercial Arbitration, 293. 
and extensively discussed by Professor Arangio-Ruiz in his second report (1989) for the International Law Commission on State Responsibility (A/CN.4/425, paras. 7-19, and Ch. 3, paras. 106-145; see also Ch. 4, paras. 146-161, 'Guarantees of Non-Repetition in the Wrongful Act'). He demonstrates wide support in the writing as well as in judicial and State practice of satisfaction as 'the special remedy for injury to the State's dignity, honour and prestige' (para. 106). ${ }^{83}$

The above quote shows that international dispute resolution bodies are open to awarding satisfaction in order to repair moral damages. Yet, the solution can be practically unsatisfying and, depending on the extent of the moral damages, should be disregarded. On the other hand, if the moral damage is minor and cannot be considered an "unacceptable breach of fundamental international rights and protections", ${ }^{84}$ which "demands a remedy beyond merely declaring it a violation of the relevant BIT", 85 it remains an available solution, as the decision in Victor Pey Casado \& President Allende Foundation v. Chile has shown.

\subsubsection{Denial of Justice}

Finally, there is one last point, examined by the Pezold tribunal, ${ }^{86}$ which is worth mentioning here that could constitute a novel basis for further research. The situation with regards to monetary compensation for moral damages potentially changes if the investment arbitration tribunal constitutes the sole forum for the claimants to seek reparation for their immaterial damage. The arbitral tribunal in Pezold added another reason for accepting that it had the competence to award monetary compensation for moral damages: a denial of justice situation. It implied that the Zimbabwean courts "may be unable to provide justice" without supplying any evidence with regard to such a claim. ${ }^{87}$ If the claimants had shown that they pursued a claim seeking compensation for moral damages in front of the Zimbabwean courts and had been refused reparation, an award of compensation could be envisaged. Of course, the same difficulty arises here that was examined above: there is no objective quantification method under international law. A worthwhile solution might be to look

\footnotetext{
83 Rainbow Warrior (New Zealand/France), Xx U.N.R.I.A.A., [122].

84 Biwater Gauffv. Tanzania, ICSID Case No. ARB/o5/22, Concurring and Dissenting Opinion of Gary Born, 18 July 2008, para. 33 .

85 Ibid.

86 Bernhardvon Pezold and Othersv. Republic of Zimbabwe, ICSID Case No. ARB /10/15, Award, 28 July 2016 , supra note 7 .

$87 \quad$ Ibid., 915-916.
} 
into the applicable principles of the host State's domestic law if the application of those principles is allowed.

\subsection{Moral Damages Suffered by Corporations' Agents}

In the Gabčikovo-Nagymaros case, the ICJ stated: "an injured State is entitled to obtain compensation from the State which has committed an internationally wrongful act for the damage caused by it". ${ }^{8}$ Yet, in investment arbitration, the victim of the wrongful act is not a State but an investor - a corporation or an individual. This opens two debates. First, is this principle also applicable to investors? And, second, can an investor claim moral damages suffered not directly by the corporation but by one of its agents?

To properly address these two questions, it is important to clarify that international investment law and the agreements and treaties it is composed of protect investments and investors depending on the terms of the investment agreement in question. As we have seen in Güneş Tekstil Konfeksiyon Sanayi v. Uzbekistan, a tribunal can deny its jurisdiction on a moral damages claim since the BIT in question does not protect "investors" but only "investments". 89 For the present discussion we assume that the underlying agreement has a very broad scope, protecting both investors (natural persons and individuals) and investments.

The first question is relatively simple to answer. Even though individuals and corporations are not subjects of classic public international law, they become a subject of international law when they take legal action against a State on the basis of a BIт. As the contracting State has ratified the BIт it gives the investors the right to take legal action if they seek to allege a breach of other rights. Applying the Gabcikovo-Nagymaros principle more abstractly, the wrongdoer has the obligation to repair the damage it has caused. This can be transposed to investment arbitration, where international law is generally applied. Therefore, in this situation, the principles stemming from the ARSIWA and ICJ judgments are applicable.

Yet, the second question reveals another conceptual problem with regard to moral damages. ${ }^{90}$ For the most part, claimants in investment arbitration are legal persons. But how can a legal person suffer from any of the various forms

88 Gabčikovo-Nagymaros Project (Hungary/Slovakia), Judgment, I.C.J. Reports 1997, para. 152.

89 Cosmo Sanderson, supra note 1, reporting on Güneş Tekstil Konfeksiyon Sanayi ve Ticaret Limited Sirketi and Others v. Republic of Uzbekistan (ICSID Case No. ARB/13/19).

90

For the opposing view, refer to Jagusch and Sebastian, supra note 76, 57 . 
of emotional distress or psychological violence ${ }^{91}$ They obviously cannot..$^{92}$ It is their employees who can suffer from these forms of moral damages.

Here, a short parenthesis is of interest. No problem arises with regard to reputational damages of legal persons. Without a doubt, a corporation can suffer from damage to its reputation. The tribunal in Desert Line stated further that "it is also generally recognized that a legal person (as opposed to a natural one) may be awarded moral damages, including loss of reputation, in specific circumstances only". ${ }^{93}$ In this case the adequate form of reparation is clearly satisfaction, as a reputational damage cannot be quantified. If the investor tries to allege a loss of business opportunities due to the loss of reputation and is able to quantify that loss, the damage would become material, thus, it would no longer be considered a moral damage.

Let us return to the issue of legal persons suffering from emotional distress or psychological violence. In Desert Line the tribunal simply stated that Yemen is "liable to reparation for the injury suffered by the Claimant, whether it be bodily, moral or material in nature. The Arbitral Tribunal agreed with the Claimant that its prejudice was substantial since it affected the physical health of the Claimant's executives and the Claimant's credit and reputation". ${ }^{94}$ Yet, the tribunal failed to explain any further how it had reached such a conclusion. If the investor were an individual, the answer to the second question would be straightforward. An individual can suffer from emotional distress or psychological violence. A legal person, however, cannot. Therefore, a legal person cannot claim moral damages consisting of emotional distress or psychological violence. On the other hand, if the investor is an individual protected under the investment agreement, he or she can, of course, suffer from emotional distress or psychological violence and therefore be in a position to claim reparation.

\subsection{The Burden of Proof}

Another complexity arising in the context of a claim for moral damages is the establishment of both sufficient evidence to prove the existence of a moral damage as well as causality between an allegedly internationally wrongful act and a moral damage. This is because a link between a non-monetary damage and the breach of a treaty protecting economic interests is not always evident.

91 S. Wittich, supra note 9 .

92 Breton, supra note 13, para. 319.

93 Ibid.

94 Desert Line Projects L.L.C. v. Yemen, ICSID Case No. ARB/05/17, Award, 6 February 2008, para. 290. 


\subsubsection{Evidence}

It does not come as a surprise that arbitral tribunals must render an informed and motivated decision. To this end, and to foster their arguments, the disputing parties submit evidence to the arbitral tribunal. This helps the arbitral tribunal "in determining the truth as to disputed issues of fact." 95 Material damages are relatively simple to prove as opposed to moral damages given the intangible nature of the latter. This point has already given rise to debate in multiple investment arbitrations.

In Rompetrol $v$. Romania the tribunal stated that to resort "to a purely discretionary award of moral solace would be to subvert the burden of proof and the rules of evidence, and that the Tribunal is not prepared to do."96 Similarly, the arbitral tribunals in Bogdanov v. Moldova and Caratube and Hourani v. Kazakhstan rejected a claim for moral damages due to a lack of supporting factual evidence. ${ }^{97}$ The same happened in Tecmed $v$. Mexico. In Tecmed, the claim for moral damages was rejected because the investor failed to provide sufficient evidence that any loss was linked to the State's action. ${ }^{98}$

The Lemire tribunal tried to apply a reality-test in order to solve this issue. According to the arbitrators, "(i)f it can be proven, that in the normal course of events a certain cause will produce a certain effect, it can be safely assumed that a (rebuttable) presumption of causality between both events exists and that the first is the proximate cause of the other."99

Said tribunal, however, was unable to provide the parties with an explanation of what this proof consists of. Furthermore, "emotional" and "psychological" damages like stress or anxiety can also occur in the "normal course of events" when investing abroad and stemming from the operations resulting from an investment. These damages can also be caused by a multitude of other factors, including acts by a third party or by the claimant itself. ${ }^{100}$

\subsubsection{Causation}

In investment arbitration practice, causation constitutes a crucial point. In brief, causation sits at the crossing point between liability and reparation.

95 Robert Pietrowski, "Evidence in International Arbitration", 22 Arbitration International (2014), 373, 373.

96 The Rompetrol Group N.V.v. Romania, supra note 57, para. 289.

97 Yury Bogdanov v. Republic of Moldova Arbitration No. V (114/2009), Award, 30 March 2010; Caratube International Oil Company LLP and Devincci Salah Hourani v. Republic of Kazakhstan, ICSID Case No. ARB/13/13 [1200 ff.].

98 Técnicas Medioambientales Tecmed, SA v. United Mexican States, ICSID Case No. ARB(AF)/ oo/2, Award, 29 May 2003 [198].

99 Lemire v. Ukraine, ICSID Case No. ARB/o6/18, Final Award, 28 March 2011, para. 169.

100 M. Lawry-White, "Are moral damages an exceptional case?", International Arbitration Law Review (2012), 10. 
Article 31 ARSIWA expressly states that the "responsible State is under an obligation to make full reparation for the injury caused by the internationally wrongful act." Hence, having established a moral damage as described above, as well as a violation of the applicable agreement, the next step is to show a link between the unlawful act and the moral damage. In various decisions arbitral tribunals have found a violation of the underlying agreement, but no damage, as the claimant failed to establish causation between the damage incurred and the unlawful act of the host State. ${ }^{101}$ Consequently, to be able to claim reparation, a claimant must be able to show that it has suffered a moral damage caused by the unlawful act of the State.

This is particularly difficult with regard to moral damages. As there is no uniform approach, different tribunals have found different tests for demonstrating causation. The tribunal in Lemire decided that "the chain of causality must be deemed proximate", 102 and found that the mere fact that the State could have anticipated the damage creates already a presumption of a causal link. It added that the fact that a State voluntarily or maliciously breaches its obligations (e.g. intimidates the investor) constitutes already sufficient proof of a causal link.

On the other hand, the tribunal in Técnicas v. Mexico refused to award compensation for reputational damage and loss of business opportunities because the claimant was not able to prove that the damage had been caused by acts that were presumably illegal under the Spain-Mexico Biт. ${ }^{103}$ In Victor Pey Casado the tribunal reached a similar conclusion. ${ }^{104}$

101 See, e.g., Urbaser S.A. \& Consorcio de Aguas Bilbao Bizkaia, Bilbao Biskaia Ur Partzuergoa v. Argentine Republic, ICSID Case No. ARB/o7/26, Award, 8 December 2016; Victor Pey Casado \& Foundation "Presidente Allende" v. Republic of Chile, ICSID Case No. ARB $/ 98 / 2$ (Resubmission Proceeding), Award, 13 September 2016; MNSS BV \& Recupero Credito Acciaio N.V. v. Montenegro, ICSID Case No. ARB(AF)/12/8, Award, 4 May 2016; Rompetrol Group N.V. v. Romania, ICSID Case No. ARB/o6/3, Award, 6 May 2013; Luigiterzo Bosca v. Republic of Lithuania, PCA Case No. 2011-05, Award, 17 May 2013; Mohammad Ammar Al-Bahloul v. Republic of Tajikistan, sCc Case No. v (o64/2008), Final Award, 8 June 2010; Nordzucker A.G. v. Republic of Poland, uncitral Arbitration Proceeding, Third Partial and Final Award, 23 November 2009.

102 Lemire v. Ukraine, ICSID Case No. ARB/o6/18, Final Award, 28 March 2011, para. 170.

103 Técnicas Medioambientales Tecmed SA v. United Mexican States, ICSID Case No. ARB/ (AF)/oo/2, Award, 29 May 2003, para. 198. And Lawry-White, supra note 100, at 10. See, for example, comments of Commissioner Bainbridge, speaking on behalf of the United States-Venezuelan Mixed Claims Commission in Dix: "Governments like individuals are responsible only for the proximate and natural consequences of their acts. International as well as municipal law denies compensation for remote consequences, in the absence of evidence of deliberate intention to injure". The Dix Case (1903-1905), IX R.I.A.A., pp. 119-121.

104 Victor Pey Casado \& President Allende Foundation v. Chile, ICSID Case No. ARB/98/2, Award, 8 May 2008, para. 689. 
However, there is no clear line of jurisprudence on how the causal link between the act of the State and the alleged moral damage can be established and proven. Generally speaking, the chain of causality between an internationally wrongful act and the damage incurred must be sufficiently proximate and clearly established by relevant evidence. This is extremely difficult to establish with regard to moral damages.

\subsection{Punitive Damages}

Furthermore, whereas a moral damage does not have an actual basis and causality is almost impossible to establish, awarding moral damages creates the impression that the arbitral tribunal is punishing the State. ${ }^{105}$ Damages are deemed punitive when the respondent is required to pay an additional sum of money on the basis of the public aim to punish that respondent and to prevent it and others from committing the same breach again. ${ }^{106}$

However, in public international law neither punitive damages nor a justification for punitive damages exists. ${ }^{107}$ These criminal law concepts have no place in international law as States are sovereign and cannot be punished. ${ }^{108}$ Consequently, an award for moral damages may be punitive and thus outside the limits of any tribunal's competence.

In the Siag case the investor did not claim compensation for moral damages caused by non-monetary losses but claimed "enhanced damages" in order to obtain complete reparation. ${ }^{109}$ The tribunal noted that by deciding in favour of Mr. Siag it would have to order Egypt to pay punitive damages even though there was no legal basis to be found either in international law or in the BIT permitting the tribunal to do so. ${ }^{110}$ By referring to the Chorzów case and the decision of the Iran-United States Claims Tribunal discussed above, the Siag tribunal confirmed that reparation has an exclusively compensatory character and that punitive damages are not available in international law. ${ }^{111}$

This principle was not respected by the arbitral tribunal in the Pezold case. It stated that "[i]n some sense, this serves not only the function of repairing

\footnotetext{
105 Parish, Nelson and Rosenberg, supra note 66, 233.

106 S. Wittich, "Compensation", Max Planck Encyclopaedia of Public International Law (2008), para. 44 .

107 Jagusch and Sebastian, supra note $76,58$.

108 Ibid., 59 .

109 Waguih Elie George Siag and Clorinda Vecchi v. the Arab Republic of Egypt, ICSID Case No. ARB/05/15, Award, 1 June 2009, para. 505.

110 Ibid., para. 544

111 Ibid., para. 545 .
} 
intangible harm, but also of condemning the actions of the offending State."112 Without drifting into speculation, the underlying message of this statement is problematic. The arbitral tribunal seems to attribute a double function to an award of moral damage: a repairing function as well as a message to the State. This is highly dangerous in terms of an excess of powers of the arbitral tribunal and the prohibition on punitive damages.

On the other hand, the tribunal in Europe Cement used the award's costs section to impose higher costs on the investor. The objective was a "dissuasive effect", suggesting a punitive element. ${ }^{113}$ The idea of the tribunal was to prevent other investors from using arbitral proceedings to bring totally unfounded claims. ${ }^{114}$ This case was a very particular case as Turkey decided to bring a counterclaim for moral damages against the investor Europe Cement, which brings us to the last issue that this article shall address.

\subsection{Moral Damages as a State's Counterclaim for Reputational Damage}

Ordinarily, in investment arbitration, an investor brings a claim against a State. Nevertheless, in investment arbitration, a State can also bring a claim for declaratory relief against an investor whose claim has been denied. In Lundin v. Tunisia, the State argued that Lundin "caused a moral damage to Tunisia by jeopardising its image with the international community and potential investors through the initiation of ICSID proceedings."115 Ultimately, the arbitral tribunal decided that the claimant had not shown any unlawful abusive behaviour by initiating ICSID proceedings and rejected the claim. ${ }^{116}$

Similarly, in the Europe Cement case Turkey requested declaratory relief as well as compensation for reputational damage. The State deemed appropriate, in accordance with the Desert Line award, a sum of USD 1 million. ${ }^{117}$

However, the investor argued that the difference between the Desert Line decision and the case at hand was that the compensation awarded in Desert Line was supposed to compensate the damage to the investor's agents' physical integrity. Hence, the key factor rested on physical harm. As this was not

112 Bernhardvon Pezold and Others v. Republic of Zimbabwe, ICSID Case No. ARB/10/15, Award, 28 July 2016, [916].

113 Lawry-White, supra note 100, at 8.

114 Europe Cement v. Turkey, ICSID Case No. ARB(AF)/o7/2, Award, 13 August 2009, para. 185.

115 Translation by the author of Lundin Tunisia B. V. v. Republic of Tunisia, ICsid Case No. ARB/12/30 [378], stating: "La Défenderesse prétend également que la Demanderesse a causé un préjudice moral à la Tunisie en portant atteinte à son image auprès de la communauté internationale et d'investisseurs potentiels en lançant une procédure CIRDI à son encontre."

116 Lundin Tunisia B. V.v. Republic of Tunisia, ICSID Case No. ARB /12/30 [379, 380].

117 Europe Cement v. Turkey, ICSID Case No. ARB(AF)/o7/2, Award, 13 August 2009, para. 128. 
the case in Europe Cement, the tribunal rejected Turkey's claim and stated that Turkey did not find itself in "exceptional circumstances", like physical harm. ${ }^{118}$ According to the tribunal, the reputational damage suffered was not sufficiently severe. In its conclusion, the tribunal stated that the mere fact that they recognised that Turkey had suffered reputational damage constituted already a form of reparation - namely satisfaction; the consequence being that the moral damage had already been repaired. This solution would be in line with the solution offered in the present article. Yet, the tribunal used the costs section in order to impose high costs on the investor. As already stated, the objective was to have a dissuasive effect, thus suggesting a punitive element. ${ }^{119}$ The idea of the tribunal was to prevent other investors from using arbitral proceedings to bring totally unfounded claims. ${ }^{120}$ Finally, the tribunal concluded that the costs would "go some way to compensating Turkey for having to defend a claim that had no jurisdictional basis and discourage others from pursuing such unmeritorious claims." ${ }^{121}$ In line with the principles evoked above that are applicable in international law, the stance of the tribunal is to be criticised as punitive damages are not considered to be available.

In Cementownia, where the facts were similar to those in the Europe Cement case, the tribunal used a different explanation. The tribunal, presided by Pierre Tercier who had also served as President for the Desert Line tribunal, stated that it was a question of four elements:

(i) Neither the ICSID Convention, nor the ICSID Convention Arbitration Rules, nor the ICsID Additional Facility Rules exclude moral damages.

(ii) The tribunal in Desert Line based its decision on a BIT and not on a general principle like the abuse of rights, which was the case in Cementownia. ${ }^{122}$

(iii) A general principle should not constitute a sufficient legal basis. ${ }^{123}$

(iv) A symbolic sum of money can be appropriate to address and condemn the abuse of rights. The tribunal hence used the costs section in order to make the investor pay.

In the end, the tribunal rejected Turkey's claim but still ordered the investor to pay an unusual amount of money in the costs section. ${ }^{124}$ This is clearly not a clean way to go as it virtually invalidates the basic mechanisms of the procedural rules. Wittich states in his article on compensation in international law

\footnotetext{
118 Ibid., para. 181.

119 Lawry-White, supra note 100, at 8.

120 Europe Cement v. Turkey, ICSID Case No. ARB(AF)/o7/2, Award, 13 August 2009, para. 185.

121 Ibid.

122 Cementownia v. Turkey, ICSID Case No. ARB(AF)/o6/2, Award, 17 September 2009, para. 169 .

123 Ibid., para. 170.

124 Ibid., paras. 171, 172.
} 
that, even if it is generally accepted that moral damages suffered by individuals need compensation, the situation regarding States is different. ${ }^{125}$ According to his research, there is not a single case in which a State has received compensation for a direct moral damage. ${ }^{126}$ It is rare that a State claims compensation for moral damages. And even if a State does so, the international courts and tribunals tend to refuse the claim, like in the Saiga case. ${ }^{127}$ Authors have expressed the opinion that "there may be good reasons why a respondent state may be entitled to an award of moral damages in addition to a declaratory judgment and attorney fees and costs". ${ }^{128}$ However, as argued above, satisfaction constitutes the only available remedy to repair moral damages. This principle must also be applied to moral damages suffered by a State.

\section{The Tests Applied by Arbitral Tribunals}

As demonstrated above, the concept of moral damages is surrounded by many controversies and the jurisprudence reflecting it is not always on the same page. Different courts and tribunals have adopted different approaches and have adopted different points of view on how claims for moral damages must be addressed. In international investment arbitration, four decisions stand out, either because the tribunals have actually awarded compensation to the investor for moral damages, or because they have tried to introduce a test for a claim for moral damages. Therefore, it is necessary to dedicate an entire section to the four awards, and to address them at length. First, the Benvenuti case is discussed, which some consider to be the first tribunal that awarded compensation to an investor. Second, the solutions found by the Desert Line tribunal are addressed. Third, the test established by the Lemire tribunal is evaluated. Finally, the award in Pezold v. Zimbabwe is discussed.

\section{1 "Ex æquo et bono" in Benvenuti \& Bonfant v. People's Republic of the Congo}

In 1977, the Italian company Benvenuti \& Bonfant commenced ICSID proceedings against the People's Republic of the Congo, alleging that $40 \%$ of its shares in a joint venture had been expropriated. In addition, they claimed CFA 250 million for "moral damages" arising out of the loss of business opportunities, loss

\footnotetext{
125 S. Wittich, "Compensation", supra note 106, para. 31.

126 Ibid.

127 ITLOS, The M/V “Saiga" case (Saint Vincent and the Grenadines v. Guinea), Prompt Release, 4 December 1997, para. 176.

128 Parish, Nelson and Rosenberg, supra note 66, 236.
} 
of credit and loss of their technical and administrative staff due to them being forced to leave the People's Republic of the Congo.

Even though the tribunal decided in favour of the investor, it still noted that the investor had not presented enough evidence to support its allegations, which the tribunal described as "mere assertions unaccompanied by concrete evidence, or even the beginning of evidence."129 Yet, it awarded compensation of CFA 5 million for moral damages to the investor, stating that, "in view of the measures to which Claimant has been subject and the suit that was the consequence thereof, which have certainly disturbed the activities of Claimant, the Tribunal deems it equitable to award it the amount of CFA 5,000,000 for moral damage". 130

As noted by Dumberry, this award has only limited significance due to two reasons. ${ }^{131}$ First, the compensation awarded was not supposed to repair the moral damages suffered by the corporate entity or its agents but rather because the events disrupted and interfered with the activities of the investor. Hence, the object of the compensation was not to effectively repair the moral damage suffered but rather to compensate the practical consequences of the damage. Second, it is important to note that the tribunal stated that the investor had not presented sufficient evidence. ${ }^{132}$ But, as the parties had agreed, the tribunal decided the case ex cequo et bono (in accordance with Article 42(3) ICsid Convention). The tribunal expressly stated that the compensation had only been awarded under its ex cequo et bono competence. As a result, the arbitral tribunal did not apply the rules of the BIT or other principles of international law.

In this context it is important to mention other arbitral disputes where a different applicable law is involved, such as when international commercial tribunals face claims for moral damages. In contrast to investment arbitration disputes, they are of no interest to this article as the applicable law is commonly domestic law. In one case a foreign investor was awarded USD 30,000,000 for

129 S.A.R.L. Benvenuti \& Bonfant v. People's Republic of the Congo, ICsid Case No. ARB/77/2, Award, 8 August 1980, English translations of French original in 21 I.L.M. (1982), 740 (with correction: 21 I.L.M. (1982)), 1478; 8 Y.B. Comm. Arb. (1983), 150; P. Dumberry, "Compensation for Moral Damages in Investor-State Arbitration Disputes", 27(3) Journal of International Arbitration (2010), 247-276, 254.

130 According to Ripinsky and Williams, CFA 5 million would today be USD 7,6oo (Sergey Ripinsky and Kevin Williams, Damages in International Investment Law (2008), at 310).

131 Dumberry, supra note 129, 255.

132 S.A.R.L. Benvenuti \& Bonfant v. People's Republic of the Congo, ICSID Case No. ARB/77/2, Award, 8 August 1980, English translations of French original in 21 I.L.M. (1982), 740 (with correction: 21 I.L.M. (1982)), 1478; 8 Y.B. Comm. Arb. (1983), 150; Dumberry, supra note 129,254 . 
moral damages: the parties had agreed that both Libyan law and the Unified Agreement for the Investment of Arab Capital in the Arab States (UAIACAS) (entered into force on 7 September 1981) was applicable to the dispute. ${ }^{133}$ In Generation $v$. Ukraine the tribunal correctly rejected a claim because the law applicable to the claim for moral damages was Ukrainian law and hence outside the scope of the tribunal's jurisdiction ratione materiae. ${ }^{134}$

Therefore, the Benvenuti award does not constitute a sufficient basis for finding solutions for the issues examined above. However, in 2008 a tribunal issued an award that awarded a specific type of compensation to an investor, to which the present article now turns.

\section{2 "Exceptional Circumstances" in Desert Line}

To the best of the author's knowledge, the first arbitral tribunal that has ever awarded compensation to an investor for moral damages is the tribunal in the Desert Line case. Desert Line was a construction company that had contracted with Yemen concerning the construction of roads in the country.

In 2004, the claimant Desert Line and the respondent Yemen submitted a dispute to commercial arbitration. The arbitral tribunal - composed of two Yemeni arbitrators - awarded a sum of USD 108 million to Desert Line. Shortly after the issuance of the award, the Yemeni armed forces and the Desert Line staff were involved in an altercation at the construction site in Yemen. As a result thereof, the Yemeni armed forces detained three directors of the investor. Following the quarrel, Yemen decided to appeal against the arbitral award and tried to obtain annulment of the award before its own courts. In the meantime, Yemen proposed the payment of USD 20 million to Desert Line in order to settle the dispute privately. Even though the investor initially objected to the deal, due to the flagrant discrepancy between the proposed amount and the amount in the original award, they finally signed the settlement agreement. Nonetheless, they continued to complain to the Yemeni authorities about the harassment, threats and theft at the hands of Yemen's armed forces, against which they had sought protection from the government. ${ }^{135}$

\footnotetext{
133 Mohamed Abdulmohsen Al-Kharafi \& Sons Co. v. Libya. For more information, please refer to: Ahmad Ghouri, "Mohamed Abdulmohsen Al-Kharafi \& Sons Co. v. The Government of the State of Libya and Others: Ad Hoc Arbitration, Final Award, 22 March 2013 (Abdel Hamid El-Ahdab, Ibrahim Fawzi, Mohamed El-Kamoudi El-Hafi)", 16 The Journal of World Investment \& Trade (2015), 325 .

134 Generation Ukraine, Inc. v. Ukraine, ICsID Case No. ARB/oo/9 [17.6].

135 Desert Line Projects L.L.C. v. Yemen, ICSID Case No. ARB/05/17, Award, 6 February 2008, para. 38 .
} 
Later, the President of Yemen refused to enforce the deal and Desert Line commenced ICSID proceedings claiming compensation for its losses arising out of the non-enforcement of the initial award, as well as for moral damages in the form of stress and anxiety suffered by its directors and for the damage to its credit and reputation. ${ }^{136}$ The Yemeni government did not object to the availability of moral damages in international investment arbitration, but rather challenged the application of the principle, alleging that Desert Line had neither presented enough evidence of moral damage nor justified the quantum of the claimed compensation, which they called an "entirely speculative estimate". 137

In the award the arbitrators referred to the above-examined Lusitania case and confirmed the availability of moral damages in investment arbitration: "Even if investment treaties primarily aim at protecting property and economic values, they do not exclude, as such, that a party may, in exceptional circumstances, ask for compensation for moral damages."138

Hence, the tribunal evaluated the circumstances of the case and considered the proof submitted sufficient to award USD 1 million for moral damages to the investor. ${ }^{139}$ Unfortunately, the arbitral tribunal neglected to explain how the quantum of USD 1 million had been determined. ${ }^{140}$ The test established by the tribunal thus focuses solely on the "exceptional circumstances", which are not further defined. The tribunal in Biwater Gauffv. Tanzania applied a similar test. Even though the tribunal ended up not awarding any compensation to the claimant (either for moral damages or for any other claims), it referred to the circumstances of the case and stated "if such claim had been advanced, the circumstances of this case (...) would render such award inappropriate". ${ }^{141}$

In a last attempt to justify their decision, the Desert Line tribunal stated that it is difficult, and almost impossible, to prove moral damages even though it is not possible to exclude moral damages simply because they are "difficult to measure or estimate by monetary standards". ${ }^{142}$

\footnotetext{
$136 \quad$ Ibid., para. 286.

137 Ibid., para. 288.

138 Ibid., para. 289 .

139 Ibid., paras. 290, 291.

140 Marc Allepuz, "Moral Damages in International Investment Arbitration" (2013), Spain Arbitration Review | Revista del Club Español del Arbitraje, 5: M. Allepuz reaches the same conclusion. The Desert Line tribunal did not "share with us how it came to the conclusion that USD 1 million was the suitable amount". Unfortunately, the author does not draw the right conclusions from his observation; namely, that the award is flawed.

141 Biwater Gauff (Tanzania) Ltd. v. United Republic of Tanzania, ICSID Case No. ARB/05/22, supra note 4, para. 808.

142 Desert Line Projects L.L.C. v. Yemen, ICSID Case No. ARB/05/17, Award, 6 February 2008, para. 289 .
} 
The Desert Line tribunal may have been the first tribunal awarding compensation to an investor for moral damages, however it failed to provide a satisfying solution with regard to the different issues it had been faced with. The "exceptional circumstances"-test is inappropriate as it only provides a wild-card to the tribunal to assess the facts according to its own standards. It merely adds another undefined term to the concept of moral damages.

\subsection{The Lemire Test}

Influenced by the Desert Line tribunal, the Lemire tribunal, composed of Juan Fernandez-Armesto, Jan Paulsson and Jurgen Voss, applied a three-tier test to the concept of moral damages that appears to be plausible. Moral damages can only be awarded if the following three conditions are fulfilled: ${ }^{143}$

(i) the State's actions imply physical threat, illegal detention or other analogous situations in which the ill-treatment contravenes the norms according to which civilized nations are expected to act;

(ii) the State's actions cause a deterioration of health, stress, anxiety, other mental suffering such as humiliation, shame and degradation, or loss of reputation, credit and social position; and

(iii) both cause and effect are grave or substantial.

Even though the tribunal refused to award compensation to the investor, the test seems rather useful and reasonable due to its high threshold. Combined with an appropriate remedy, the Lemire three-tier test could constitute a solution for establishing the existence of moral damages that must be repaired. The test has already been applied in Stati v. Kazakhstan, ${ }^{144}$ and also in Tza Yap Shum v. Peru, ${ }^{145}$ where the tribunal rejected the claim for moral damages. Authors have criticised the Tza Yap Shum tribunal for doing so, but gave no satisfying explanation as to why the Lemire test is not adequate. ${ }^{146}$ Of course, the test does not constitute any binding obligation under international law. Yet, it can be the starting point for the establishment of a harmonised solution with regard to the establishment of moral damages.

\subsection{Application of the Lemire Test in Pezold}

On 28 July 2015, an ICSID tribunal rendered an award in Pezold v. Zimbabwe, ordering Zimbabwe to return to the Pezold family the farms and farmland it had seized without compensation following the enactment of a land reform

\footnotetext{
143 Lemire v. Ukraine, ICSID Case No. ARB/o6/18, Final Award, 28 March 2011, para. 333.

144 Anatolie Stati, Gabriel Stati, Ascom Group SA and Terra Raf Trans Traiding Ltd v. Kazakhstan, scc Case No. v (116/2010) [1784].

145 Señor Tza Yap Shumv. The Republic of Peru, ICSID Case No. ARB/o7/6 [281].

146 Wong, supra note 67.
} 
in 2005. Additionally, the claimants were seeking moral damages for the threats, violence, stress and anxiety inflicted by illegal settlers on their land. The arbitrators applied the Lemire test and, wrongfully, awarded compensation for moral damages to the claimants. ${ }^{147}$ Basing its decision on Desert Line, the arbitral tribunal noted that "(...) although it is difficult to substantiate an appropriate sum for moral damages, the Tribunal [in Desert Line] indicated that this should not be a deterrent."148

Using the Lemire test, the tribunal discussed the moral damages suffered by three different claimants: Heinrich, "Other von Pezold Claimants" and "Border Claimants". Whereas it rejected the claim for moral damages allegedly suffered by the "Other von Pezold Claimants" (due to them not having been physically present in Zimbabwe), it granted USD 1,000,00o to both Heinrich and the "Border Claimants" for stress and anxiety. ${ }^{149}$ There is no doubt that such damages can be severe and warrant reparation. In this instance, applying a threshold test, such as the Lemire test, seems appropriate.

In the section on moral damages, the arbitral tribunal did not properly discuss the nature of the USD 1,000,000 awarded. However, in paragraph 925 of the decision it listed "moral damages" as part of "other compensation". 150 As a result, it can be assumed that the arbitral tribunal considered that the moral damages were to be repaired through compensation.

However, the decision to award compensation is flawed as current international law does not provide for a basis of objective quantification. Unfortunately, the arbitral tribunal did not seize the opportunity to rely on a statement by the respondent in order to clarify the nature of their moral damages award. The respondent had stated that " $[\mathrm{s}]$ hould any moral damages be awarded, the Respondent asks that they be greatly reduced to be symbolic in nature (see Rejoinder, para. 20.1.7)."151 The respondent seems to have accepted that a monetary reparation can be awarded and did not even bring it up in the annulment proceedings. ${ }^{152} \mathrm{~A}$ discussion of the "symbolic" nature of moral damages could have been helpful, instead of rejecting such approach and referring to the "full reparation" standard. Even if a monetary satisfaction is subjective, it nonetheless allows the arbitral tribunal to decide on an appropriate reparation.

\footnotetext{
147 Bernhard von Pezold and Others v. Republic of Zimbabwe, ICSID Case No. ARB/10/15, Award, 28 July 2016 , supra note 7 .

148 Ibid., 910.

149 Ibid., 921, 923.

15 o Ibid., 925 .

$15^{1}$ Ibid., 906.

152 Bernhard von Pezold and Others v. Republic of Zimbabwe, ICSID Case No. ARB/10/15, Decision on annulment, 21 November 2018.
} 
Even though the conceptual framework of public international law does provide for some solutions and answers, arbitral tribunals have had difficulties with the concept of moral damages. This is the case because (1) moral damages can be repaired through monetary satisfaction as well as satisfaction in its purest form; (2) legal persons cannot claim reparation for moral damages suffered by their agents; (3) it is almost impossible to prove a moral damage and establish a causal link; (4) punitive damages are neither available nor allowed under international law; and (5) States can claim reparation for their reputational damage.

Furthermore, the solutions and tests found by the tribunals in Benvenuti and Desert Line are not adequate. Yet, by combining the Lemire test with the obiter dictum in Victor Pey Casado, the only satisfying solution to this dilemma is already on the table. Awarding compensation to an investor having suffered from material damages clearly makes sense. The Lemire tribunal applied a three-tier test for the award of moral damages. This test consists of three conditions: first, the State's actions imply an ill-treatment that contravenes the norms according to which civilised nations are expected to act; second, the State's actions cause a deterioration of health, stress, anxiety, or other mental suffering; and, third, both cause and effect are grave or substantial. In addition, according to the Pey Casado obiter, the moral damages can be repaired by satisfaction. Whereas here the tribunal referred to satisfaction as declaratory relief, monetary satisfaction is also available. In this manner, the investor receives full reparation.

Moreover, we have seen that a legal person cannot claim reparation for moral damages, such as emotional distress or psychological violence, suffered by its employees. Unless there is a "full protection and security" clause in the relevant instrument, such damages cannot be claimed in front of an arbitral tribunal. However, a legal person can suffer from reputational damage, which can be repaired through satisfaction. If the investor is an individual, he or she can suffer from both emotional distress, psychological violence and reputational damage.

Additionally, tribunals have noted that it is difficult to establish a link between non-monetary damage and the breach of a treaty protecting economic interests. The evidence must be sufficiently clear to prove a chain of causality that is sufficiently proximate.

Furthermore, we have seen that reparation for moral damages for investors that have suffered at the hands of States that were acting maliciously can have a punitive character, which is prohibited under international economic law. As 
a result, arbitral tribunals must refrain from according "hidden compensation", which has a punitive character, to the damaged party.

Finally, States can claim reparation for reputational damage. As this article has argued, this is possible when the arbitral tribunal decides to accord some form of satisfaction to the State.

It is to be seen how future tribunals facing claims for moral damages will decide (for example in Mykhailenko v. Belarus ${ }^{153}$ and BSG Resources v. Guinea) ${ }^{154}$ It can be concluded that the solutions that have been evoked above would be available under international law.

153 Mr. Gennady Mykhailenko \& United Pipe Export Company Trading Ag v. The Republic of Belarus, Notice of Intent to Submit Dispute to Arbitration, 2 August 2013.

154 BSG Resources Limited, BSG Resources (Guinea) Limited and BSG Resources (Guinea) SÀRL v. Republic of Guinea, ICSID Case No. ARB/14/22. 